5. Ермошин Ю. А. О роли и языковых средствах эмоциональной выразительности в официальной публичной речи. Вестник Российского университета дружбы народов. Серия «Лингвистика». Москва, 2011. № 4. C. 5-10.

DOI https://doi.org/10.30525/978-9934-26-073-5-1-46

\title{
METAPHORS IN PSYCHOLOGICAL TERMINOLOGY IN ENGLISH AND SPANISH
}

\author{
Bobchynets L. I. \\ Candidate of Philological Sciences, \\ Associate Professor at the Department of Romance Philology \\ and Modern Greek and Translation \\ Kyiv National Linguistic University \\ Kyiv, Ukraine
}

Terminology of Psychology is scientific and precise, though we observe metaphors, in particular in Cognitive Psychology which studies mind, mental processes and characteristics, perception, memory, etc.

There exist three main metaphors referring to mind: metaphor of a computer (metáfora de ordenador), metaphor of brain (metáfora de cerebro), narrative metaphor (metáfora de narración). The metaphor of a computer is a model of cognitive sciences. According to R. Gardner, this metaphor left aside emotional, historical, cultural, sociological and contextual factors because computers do not have emotions [3, p. 34]. This made possible to look separately at cognitive and emotional processes. The analogy is of functional character, therefore cognitive terms include computational language: inputoutput, software-hardware, random access memory, etc. According to the computer metaphor, cognition is represented as a mechanism of processing information. Cognition as a computer is of representational character. The structures of memorization are viewed as hardware of computers. Metaphoric descriptions of mental processes exist not only in the sphere of Psychology but also in every day speech, for example, we may say to be blocked / estar bloqueado to refer to the state of being unable to think, to be disconnected / estar desconectado referring to the loss of consciousness, process and store information / procesar y almacenar la información, etc. These are «mechanized» or «computerized» human characteristics [6]. J. Soto Ramírez gives examples of the opposite phenomenon, «humanization of a computer», metaphors which represent computers as humans: computers may be ill, may 178 
have viruses. At the same time there is a metaphor which states that thinking is computation / pensamiento es computación [6]. Though, as M. de Vega puts it, such metaphor which belongs to the symbolic computational paradigm is in crisis, as representing the mind as a computer processing information, does not take into consideration the concept of the universal mind which integrates qualitative aspect of cognition such as conscience, emotions [9, p. 33].

The brain metaphor is a connectionist concept representing the mind as a natural model of neuronal nets to explain cognitive processes. This idea was popular in the 1960s and later in the 1980s. The development of cognitive anthropology, neurosciences and linguistics which treat language as a cognitive phenomenon, made this metaphor functional, as it proved the interdisciplinary and multidisciplinary character of mind and cognitive sciences.

Narrative metaphor is related to the concept of the meaning and importance of construction of stories. Thus, J. Bruner suggests the necessity to «restore mind» by the concepts originated from Humanities through cultural and social contexts. J. Bruner insists that computers are not able to create representations, meanings or cultures [2, p. 68]. The main function of mind is to narrate stories and attribute meanings to them. The three significant characteristics of any narration are sequence, possession of an internal structure which is indifferent to extra-linguistic reality, canonic character of the narration. The main function of narration is to elaborate schemes which enable construct the world as the alternative to chaos. Narrative function of mind is useful to understand and explain the functioning of autobiographic memory, individual conscience and cognitive processes which support the self.

Besides metaphors as terms in Psychology, there are metaphors used in psychological practices, for example, in CBT (Cognitive Behavioral Therapy). Such metaphors have therapeutic function, meanwhile the function of terminological metaphors is nomination. The works of Lakoff and Johnson stimulated study of metaphors in cognitive and clinical psychology. For instance, such metaphors as black-and-white thinking / pensamiento blanco y negro, mind-reading / lectura mental help clients become more aware of their cognitive processes.

The huge potential in the use of metaphor in Psychotherapy, and especially in CBT, has been demonstrated by the publications by R. Stott [8] and J. Stoddard and N. Afari [7], useful to therapists. To be functional, metaphors need to be adapted to the client. J. Bennett-Levy describes that a metaphor of growth the seeds of change / semillas de cambio can help clients start planning and problem solving in their lives by using what they know of cultivating a garden [1, p. 122].

Two other metaphors which can be helpful are black glasses / gafas negras and blinders / anteojeras, put on a horse to limit its range of vision. When 
people are depressed, it is as if they are wearing glasses with black lenses. The information they receive from their environment passes through the dark lenses. So they tend to view their experiences in a very negative way [4].

According to K. Moser, the burdened camel / camello sobrecargado is a metaphor for stress. It represents the idea of a camel with a huge pack of straw on its back. The camel's load is unbearably heavy and the poor animal is going to break down (or be brought to its knees). Therefore, some straw needs to be removed very quickly in order for the load to be bearable [5]. Alternative metaphor in a stressful situation is they have a lot on their plate / tienen mucho en su plato. It creates awareness that things are critical and something needs to be done immediately. What is urgently needed is to reduce the load. One of the metaphors in working with young people suffering eating disorders is based on the concept of rowing upstream against a strong current / remar contra la corriente fuerte [4].

Future studies may be focused on «a transdisciplinary or interdisciplinary perspective on metaphors which would not only bring cognitive, cultural, social and individual aspects of metaphor use closer together, it would also promote the triangulation of qualitative and quantitative research paradigms» $[5]$.

In conclusion, we would like to emphasize that psychological terminology possesses dynamic character, as the science is constantly developing and we expect new metaphors appearing to denominate mental processes or other internal characteristics. New vivid metaphors in psychological therapy can be studied within interdisciplinary approach of linguistic and psychological sciences.

\section{References:}

1. Bennett-Levy J., Thwaites R., Haarhoff B., Perry H. Experiencing CBT from the Inside Out: A Self-Practice / Self-Reflection Workbook for Therapists. New York: The Guildford Press, 2015. 278 p.

2. Bruner J. Acts of meaning. Cambridge MA: Harvard University Press, 1990. $181 \mathrm{p}$.

3. Gardner R. C. Social psychology and second language learning: The role of attitudes and motivation. London: Edward Arnold, 1985. 208 p.

4. Killick S., Curry V., Myles P. The mighty metaphor: a collection of therapists' favourite metaphors and analogies. Cambridge University Press online, 2016. Retrieved from https://www.cambridge.org/core/journals/thecognitive-behaviour-therapist/article/mighty-metaphor-a-collection-of-therapists-favourite-metaphors-and-analogies/A2FDDEB0C9BA9B4FE7103A73 C0455B6D

5. Moser K. S. Metaphor Analysis in Psychology - Method, Theory, and Fields of Application. Forum Qualitative Sozialforschung / 180 
Forum: Qualitative Social Research, 2000. 1 (2). Art. 21. Retrieved from https://www.qualitative-research.net/index.php/fqs/article/view/1090/2387\# text=Metaphors\%20represent $\% 20$ general\%20cognitive\%20abilities,of\%20und erstanding\% 20 and $\% 20$ self $\% 2$ Ddefinition.

6. Soto Ramírez J. Metáforas, Complejidad y Psicología. Tiempo. Laberinto, 2018. Retrieved from https://xdoc.mx/documents/metaforascomplejidad-y-psicologia-5ec59c9bc7f05

7. Stoddard J, Afari N. The Big Book of ACT Metaphors: A Practitioner's Guide to Experiential Exercises and Metaphors in Acceptance and Commitment Therapy. Oakland: New Harbinger, 2014. 272 p.

8. Stott R, Mansell W, Salkovskis P, Lavender A, Cartwright-Hatton S. Oxford Guide to Metaphors in CBT: Building Cognitive Bridges. Oxford: Oxford University Press, 2010. 260 p.

9. Vega de, M. Introducción a la psicología cognitiva. Madrid: Alianza Editorial, 1998. 568 p.

DOI https://doi.org/10.30525/978-9934-26-073-5-1-47

\title{
TWO MOTIVATIONAL COMMENCEMENT SPEECHES FOR UNDERGRADUATES
}

\author{
Bodnar I. M. \\ Candidate of Philological Sciences, \\ Associate Professor at the Department of Foreign Languages for Sciences \\ Ivan Franko National University of Lviv \\ Solohub L. V. \\ Candidate of Philological Sciences, \\ Associate Professor at the Department of Foreign Languages for Sciences \\ Ivan Franko National University of Lviv
}

\section{Komar R. I.}

Lecturer at the Department of Foreign Languages for Sciences Ivan Franko National University of Lviv Lviv, Ukraine

It is not a secret that people need motivation to perform better - at school, at work or whenever else. The best way to develop yourself is to see someone else's example of success [2, p.4080]. It has been proved that motivated 